\title{
Family Life for Children in State Care
}

\section{An Analysis of the European Court of Human Rights' Reasoning on Adoption Without Consent}

\author{
Clarie Breen \\ Professor, Te Piringa Faculty of Law, University of Waikato, Hamilton, \\ New Zealand \\ claire.breen@waikato.ac.nz \\ Jenny Krutzinna \\ Postdoctoral Researcher, Centre for Research on Discretion and Paternalism, \\ Department of Administration \& Organization Theory, University of Bergen, \\ Bergen, Norway \\ jenny.krutzinna@uib.no
}

\section{Katre Luhamaa}

Researcher, Centre for Research on Discretion and Paternalism, Department of Administration \& Organization Theory, University of Bergen, Bergen, Norway

katre.luhamaa@uib.no

\section{Marit Skivenes}

Professor, Centre for Research on Discretion and Paternalism, Department of Administration \& Organization Theory, University of Bergen, Bergen, Norway

Corresponding author: marit.skivenes@uib.no

\begin{abstract}
This paper examines what set of familial circumstances allow for the justifiable interference with the right to respect for family life under Article 8, ECHR. We analyse all the Courts' judgments on adoptions from care to find out what the Court means by a "family unit" and the "child's best interest". Our analysis show that the status and respect of the child's de facto family life is changing. This resonates with a view that children do not only have formal rights, but that they are recognised as individuals
\end{abstract}


within the family unit that states and courts must address directly. Family is both biological parents and child relationships, as well between children and foster parents, and to a more limited extent between siblings themselves. The Court's understanding of family is in line with the theoretical literature, wherein the concept of family reflects the bonds created by personal, caring relationships and activities.

\section{Keywords}

children's rights - European Court of Human Rights - adoption - right to respect for family life

\section{Introduction}

Roald Dahl's famous novel Matilda (1988), about the five-year-old Matilda who is neglected by her family and does not fit into her birth family's culture and preferences, has an interesting teaching line. The story ends with Matilda initiating adoption proceedings, so that she can change family, and that the lovely Miss Honey adopts Matilda and becomes her parent. Roald Dahl is revolutionary in his approach to family, with Matilda making a choice to select a new family, and at that time, that an unmarried woman would be allowed to adopt a child and be considered a family. In this paper we examine what set of familial circumstances allow for the justifiable interference with the right to respect for family life.

Societies have long accepted - morally, legally and politically - that parents can give up their children to be raised by others, so that de facto responsibility for a child is transferred from the birth parent(s)' family to another adult(s). Often it is family members that care for these children, and without the State or anyone else being involved in transferring authority over children. The reasons for this practice have been circumstances such as poverty, health issues, moral shame (e.g. for children born out of wedlock), or work obligations (e.g. women and men leaving their children with others to work in other countries for years). Societies accept that children can be adopted by others so that de facto and de jure responsibility for the child are transferred from birth parents to other(s). ${ }^{1}$ The parents' freedom and authority to give up

1 For a comprehensive historical account of adoption, see Barbara Bennett Woodhouse, "Waiting for Loving: The Child's Fundamental Right to Adoption", 34 Capital University Law Review, 297-329, 309-316. We have limited information about step-parent adoptions. 
their child for adoption is, in most European countries, a simple procedure demanding consent from parents with parental rights and from the child (consent competency is set to a fixed age from ten years and older in the majority of the European countries $(\mathrm{N}=30)$ ) (Fenton-Glynn, 2013: 594-5). Irrespective of whether the transfer of care is temporary or permanent, de facto or de jure, children have hardly been heard in these situations. The cultural acceptance of adoptions probably varies, as indicated by the fact that this only rarely happens in some countries and more often in others; and some countries have even made adoptions a topic for their TV shows, for instance, "16 and pregnant" (US) and "Find me a family" (UK).

However, when the State interferes with parents' freedom and authority in child protection situations, for instance by limiting or terminating parental rights due to the interests of the child, controversies on moral, political and legal grounds are raised. The State has an obligation to protect the rights of the child and must intervene if there is evidenced abuse or neglect of a child (Gilbert et al., 2011; Kilkelly, 2017; Burns et al., 2017). The United Nations Convention on the Rights of the Child (CRC), ratified by all States in the world except the USA, prohibits the involuntary separation of children from their parents unless such separation is deemed necessary for the best interests of the child (Article 9(1)). Although the CRC does not contain a specific right to respect for family life, it is strongly premised on the view that the child's rights are best secured in the context of family life. ${ }^{2}$

In Europe, there are millions of children that have been removed from their parents due to abuse and neglect, and if not adopted, many of them will live most of their childhood in public care (Burns et al., 2017; Berrick, Gilbert and Skivenes, in press). Parents in all European states can bring their case before the European Court of Human Rights (ECtHR or Court) if they believe their human rights have been violated by the state. Children have the same right, as Article 1 of the European Convention on Human Rights (ECHR or Convention) extends the right contained in the Convention to "everyone". Cases studied in this article have been initiated by parents, although cases about violations of family rights will typically also involve children. Nevertheless, it has been noted that the child's perspective in these judgments is often virtually invisible and the practice of the Court focuses on the rights of the parents instead of those of the child (Kilkelly and Bracken, 2017). The sole purpose of the

2 Articles 5, 9-11, 18(1) and (2), 20-21, 25 and 27(4) are the rights that are particularly pertinent to the child's right to respect for family life, with Articles 9,20 and 21 being particularly relevant to children's rights in adoption proceedings. 
ECtHR is to interpret the ECHR and to analyse whether national practice by State Parties complies with it. The central aim of the Court is to develop principles that could be embedded in the national legal system (Spano, 2018). As such, the jurisdiction of the Court is subsidiary to that of the member states, which in Article 8 cases means that the states have wide discretion in planning and executing their policies on family and child. The Court does not interfere unless clear procedural mistakes have been made, or core elements of the right to respect for family life have been violated (cf. Asche 2017, ECtHR 2019). The ECtHR is authoritative in its interpretation of human rights, and its decisions have an impact on member states' practice (Zysset, 2018: 94-96). Thus, it is of vital importance to examine how the Court approaches and understands the child's family relations, and if the Court acknowledges children's right to respect for family life.

In this paper, we study how a child's right to respect for family life and the child's right to have her best interests considered, are understood and interpreted for children who are in public care with no prospect of being reunified with their birth parents. Our research focuses on adoptions that stem from placement of children into public care, and the subsequent decision to place children for adoption that is resisted by the birth family, and thus is "involuntary". The empirical material for our analysis consists of all cases concerning contested adoptions from care which have been decided by the ECtHR in the period from 1959-2018 ( $=20)$. We examine how the Court reasons and balances parental and children's rights, assesses the child's de jure and de facto family life, and determines the child's best interests in cases where the family unit that the child is born into cannot provide for and raise the child.

The article is structured in seven parts. The next two sections outline the concept of family in theory and jurisprudence, respectively, followed by a presentation of the workings of the Court and a method section. Thereafter, we present our findings, discussion and concluding remarks.

A simple and direct definition of family, widely used, is that it is a multigenerational unit consisting of one or more adults, taking primary custodial responsibility for any number of dependent children (Archard, 2010: 9-10). Typically, a family will live together and have an intimate and close relationship, but these are not necessary conditions. A necessary condition is that 
this unit must be stable, in the sense that the parent-child relationship needs to exist over a presumable substantial period of time. By this definition, temporary foster care, for example, would not be considered family, as it lacks permanence being based on a contract, which can be terminated by the state or the foster parents (and sometimes the child). In a somewhat different approach to defining family, the child-adult relationship is not a necessary condition, and the criteria centre around relations and activities instead: "people related by marriage, birth, consanguinity or legal adoption, who share a common kitchen and financial resources on a regular basis" (Sharma, 2013: 307). Social work research increasingly tends to define family based on caring relationships, placing the focus strictly on function over form: those caring for a particular person are considered family, regardless of the presence of a parent-child relationship (Cutas, 2018). The concept of family is also shaped by normative assumptions about personal relationships, which is evident from the tensions between legal and moral parenthood and the different views on what makes a parent or a family.

Importantly, the family is not simply a private realm, but it is also a social institution supported by laws. Political theorist John Rawls (2001) considers the family to be both private and public, as the family is the basic structure of society but simultaneously lies outside this structure. Families are voluntary and non-voluntary units that involve both individual and public ends, and thus must be both free from state interventions but also require state protection of individual members. Feminists, for example, argue that the family should be subject to principles of justice, as the state cannot avoid interference in families, especially given the state's critical interest in children as future citizens (Satz, 2017). For the purpose of our study, "family" is to be considered a two-generation unit, and entails a broad non-contractual parent-child relation criterion that includes both de jure and de facto parents.

\section{The Concept of Family in Jurisprudence}

Family as a concept, including the right to respect for family life, is present in many international human rights instruments (Banda and Eekelaar, 2017). There are two main sources of children's rights for the Member States of the Council of Europe: the ECHR and the CRC. Both legal frameworks protect the child's right to respect for family life but in quite distinct ways. 


\section{1}

\section{Article 8 of the ECHR and the Case Law of Article 8}

As one of the two main sources of children's rights for Member States of the Council of Europe, Article 8 of the ECHR states:

1. Everyone has the right to respect for his private and family life, his home and his correspondence.

2. There shall be no interference by a public authority with the exercise of this right except such as is in accordance with the law and is necessary in a democratic society in the interests of national security, public safety or the economic well-being of the country, for the prevention of disorder or crime, for the protection of health or morals, or for the protection of the rights and freedoms of others.

This right, and its limitations, apply to everyone. Although the wording of Article 8 may appear straightforward, the nature of the "family" which lies at the core of the right to be protected is open to a variety of interpretations and has been the subject of much jurisprudence by the ECtHR. This has been driven by ongoing social change reflecting the evolving nature of the ECHR (see e.g. Dzehtsiarou, 2011; Lagoutte, 2016; Hodson, 2012).

The ECtHR has established that domestic measures hindering the enjoyment of family life amount to an interference with the right protected by Article 8; and that any such state action has to be rooted in national law, must be justified for the protection of the health and welfare of the child, and be necessary in a democratic society (Directorate of the Jurisconsult, 2019). The notion of necessity implies that the interference corresponds to a pressing social need and, in particular, that it is proportionate to the legitimate aim pursued, which in our cases is an overriding requirement pertaining to the child's best interests. There is a wide margin of appreciation enjoyed by the states, and the Court's task is not to substitute itself for the domestic authorities (for general principles, see e.g. Kilkelly 2017: 17-31).

The Court analyses the facts of the case in the context of applicable national and international legislation such as relevant provisions of the CRC and the European Convention on the Adoption of Children. Although the Court is not formally bound by the provisions of other supranational legal regimes, it does refer to them in the context of relevant law. Neither is the Court bound by its previous case law but as it elucidates, clarifies, and sometimes develops the rights protected by the Convention (see e.g. Zysset 2017: 121-124, 133-138) and aims for consistency of practice, it routinely refers to its previous case law (Directorate of the Jurisconsult, 2019, paras. 22-24, 242-244). As Wheatle (2017: 107) observes, the Court has to guarantee interpretative integrity of its practice; thus, the practice has to be both backward and forward-looking. 
Where a right to respect for family life has been established, the state has an obligation to protect it, including through positive measures (e.g. Kilkelly, 2010; Rainey, Wicks and Ovey, 2017: 370-374, 376-386). Nevertheless, the parents' right to respect for family life may be overridden by the child's best interests, which may require prioritising the child's existing or emerging bonds with her non-biological family (see Kilkelly, 2017:159-163 for a general overview of the principles relating to family ties; and ECtHR, 2019 April, paras. 299-308 for key practice). This means that the Court might establish a violation of the right to respect for family life of the parents (and compensate it appropriately), but that the state has no obligation to recreate the family life with the biological family. ${ }^{3}$

\subsection{The Concept of Family in the cRc and in the CRC Committee}

The CRC is the second key source of children's rights for members of the Council of Europe and adds some extra elements to the decision-making process. Although the CRC does not contain a specific right to respect for family life, it is strongly premised on the view that the child's rights are best secured in the context of family life. This much is indicated by preambular paragraph 6 of the CRC which provides:

Convinced that the family, as the fundamental group of society and the natural environment for the growth and well-being of all its members and particularly children, should be afforded the necessary protection and assistance so that it can fully assume its responsibilities within the community.

This theme of the centrality of the family is supported by the wording of Article 5, which requires States Parties to respect the responsibilities, rights and duties of parents as the latter "provide, in a manner consistent with the evolving

3 The Court discussed this in Johansen v. Norway (ii) (2002), admissibility decision where the mother contested the continuing placement of the child with foster parents even after the ECtHR had established a violation of the Convention. The Court pointed out that the national County Board correctly, 'laid stress on the need to secure S.'s position in the foster-home environment. In this connection, particular regard was had to her age (then 8) and maturity, the fact that she had no social ties with her biological mother and had lived nearly all her life with her foster parents, whom she regarded as her own parents, and had developed a particularly strong attachment to them. The foster parents had proven themselves suitable carers for S. Removing her from the foster-home environment would not only be damaging to her in the short term but was also likely to have adverse effects in the long term. Indeed, at that point, the applicant did not dispute the view held by the child-welfare services that the foster-home placement was in S.'s best interests.' 
capacities of the child, appropriate direction and guidance in the exercise by the child of the rights recognised in the present Convention". The importance of the relationship between children and their parents is further underpinned in Articles $7,8,18$, and $27(2)$. That familial relationships can be broken is also reflected in Articles 9-11 and 20-21, and these articles also highlight the centrality of the role of the state in such situations. These provisions make explicit reference to the need for all decision-making to be informed by the child's best interests, a requirement that is further reinforced by the provisions of Article 3(1) whereby the best interests of the child is to be a primary consideration in all decision making regarding the child, and the status of the best interests of the child as a guiding principle of the CRC (for general principles of the CRC see e.g. Hanson and Lundy, 2017). Notably, for those States Parties that recognise and/or permit the system of adoption, Article 21 requires that such States "shall ensure that the best interests of the child shall be the paramount consideration". ${ }^{4}$ In essence, it means that if there is a need to balance the different rights, the best interests of the child should prevail (van Bueren, 2007; Eekelaar, 2015; cf. Reece, 1996).

Broadly speaking, the CRC's provisions regarding the child's right to respect for family life mirror the interpretation of the right to respect for family life in Article 8(1) ECHR, in that children ought to be cared for within a family environment. With regard to adoption, the right of the child to family life has been considered in a number of General Comments of the Committee of the CRC, which - although non-binding, are authoritative interpretations - strongly reaffirm the requirement to consider the best interests of the child (CRC, 2013: para. 29). In the situation of adoptions, this principle must be the "paramount" consideration (CRC 2013, para. 38). The issue of adoption has also been mentioned in other General Comments that have been released by the CRC Committee, such as the one on the implementation and protection of rights in early childhood (CRC, 2005: para 36(b)), as well as in a Joint General Comment (CRC CMW, 2017: para. 32(e)). Elements of these General Comments are also significant because of their emphasis on obtaining the views of the child in determining the child's best interests (CRC, 2005: para. 36(b); CRC, 2009: paras. 32-33, 56; CRC, 2016: para. 39). This emphasis placed on the child's views in determining the best interests of the child, marks a difference between the approaches of the CRC and the ECtHR in decisions regarding family care, alternative care and adoption.

4 Sloan (2013) discusses the implementation of the CRC in the field of adoption law in UK, and argues that there are difficulties with the notion of "paramountcy" of the best interest principle. 


\subsection{Congruence between the ECtHR and the Committee of the CRC}

Despite a degree of congruence between the ECtHR and the Committee of the CRC, it should be noted from the outset that, as a matter of international law, neither legal regime is bound by the other. Although the ECtHR is not obliged directly to use the CRC or its interpretive documents as its main source for decision making, it is helpful to consider how the principle of the child's best interests is understood within the framework of the CRC. In terms of the actual relationship between the two legal regimes, empirically, an analysis of all child protection care order cases decided by the Court from 1959-April 2016, show that the CRC is rarely mentioned by the Court (Helland, 2019). ${ }^{5}$

The CRC Committee has addressed the lack of common understanding of the best interests principle (CRC General Comment No. 14, 2013), listing seven elements that should be considered when a decision about the child's best interests is to be made (7ff.): (a) the child's views; (b) the child's identity; (c) preservation of the family environment and maintaining relations; (d) care, protection, and safety of the child; (e) situation of vulnerability; (f) the child's right to health, and (g) the child's right to education. Each of these elements is laid out in detail in the Comment and should provide clear instructions for decision makers across countries. However, because this principle covers all aspects of a child's life, the comment also underscores that the principle remains ambiguous, and that ' $(t)$ he content of each element will necessarily vary from child to child and from case to case, depending on the type of decision and the concrete circumstances, as will the importance of each element in the overall assessment.' (9). A study of the child's best interests principle in child protection legislation of 14 western countries reveals that prominent factors in legislation are: the child's views; the preservation of the family environment and maintaining relations; care, protection and safety of the child, and a situation of vulnerability. However, the child's identity and the child's rights to health and to education are only mentioned by a few countries (Skivenes and Sørsdal, 2018).

It is also worth noting that a review of the Concluding Observations made by the CRC Committee in relation to the six countries that feature in our analysis show that the CRC Committee has expressed concern at the manner in which those six countries have applied this standard in the context

5 In the Court's life span up till 2016, there have been decided 44 cases involving child protection care orders, the first decided in 1987 (Helland, 2019), and the first time the CRC was mentioned by the Court in these 44 judgments was in 1996, and in total the CRC has been mentioned in ten of these judgments. 
of situations of alternative care. ${ }^{6}$ This is relevant to the present context of adoptions from care, which are typically preceded by such alternative care arrangements.

We analyse all judgments that concern an adoption from care decided by the Court from its start in 1959 until the end of December 2018. We have used the HUDOC database that contains all the judgments, decisions and resolutions made by the ECtHR. We have selected the English language judgments that were decided either by the Grand Chamber or the Chamber ${ }^{7}$ under Article 8 , and that have importance levels "key cases", 1 or 2 . We had the following search strategies. First, we searched text strings that included all the following words: "child"; "adopt"*; and "welfare*". This search resulted in 118 cases (11 December 2018). Testing for accuracy in our search strategy, we searched for references to two cases: "Johansen $v$. Norway" (resulting in 65 cases) or "Aune $v$. Norway" (resulting in 8 cases), and they were included in the first search and thus confirmed the relevance of the search strategy. Second, all 118 cases were manually reviewed to identify if they were adoption from care cases. The result is a total of 20 cases that deal with termination of parental rights resulting in adoption or declaring the child available for adoption. We examined the Court's reasoning in these 20 cases to identify whether the Court emphasised the procedural or substantial elements (cf. O'Mahony, 2019) in the best interests considerations. ${ }^{8}$ In half of the cases, the Court focused on a procedural element of either Article 8 or Article 6 of the ECHR (e.g. discussing failures to involve the applicant sufficiently during the proceedings, the length of judicial proceedings in the national justice system, or inappropriate procedures for restricting or terminating access to the child, the procedure of removal, or access to the child or adoption). In ten cases, what we label "core cases",

6 See the Concluding Observations of the CRC Committee: Croatia 1996a, para. 10; Slovenia 1996b, para. 17; Norway 200o, paras. 34-35; Spain 2002a, paras. 32 and para. 33(a)-(b); UK 2002b, para. 26; Italy 2003, paras. 33-35; Slovenia 2004a, paras. 34-35; Croatia 2004b, paras. 42 and 48; Norway 2005, para. 24; Norway 2010a, paras. 34-35; Spain 201ob, para. 27; Italy 2011, para. 42(a); Slovenia 2013, paras. 28-29 and 48-49; Croatia 2014, paras. 4O(a)-(b) and 41(b); UK 2016, paras. $5^{2}$ and $53(\mathrm{~b}),(\mathrm{c})$ and (g); Spain 2018a, paras. $27(\mathrm{a})-(\mathrm{b})$ and $28(\mathrm{a})-(\mathrm{b})$; and Norway 2018b, paras. 20-21.

7 This method of selection excludes admissibility decisions that might have relevance for defining the protective scope of article 8 .

8 We are aware that decisions on best interests are interwoven with the procedural aspects of a decision, and thus the distinction we have made may be subject to discussion. 
the Court discussed the material scope of Article 8, including themes such as the justifications provided for restrictions to/termination of contact, considerations of alternatives to a permanent severing of ties with the biological family or the appropriate balancing of parental rights against the best interests of the child. For transparency purposes, we provide an Appendix with supplementary material published online at: https:/www.discretion.uib.no/wp-content/ uploads/2019/10/Breen-et-al.-Family-life-for-children-in-state-care.pdf.

The 20 cases are as follows, with the 10 core cases emboldened: $B$. $v$. The United Kingdom (1987); H. v. The United Kingdom (1987); O. v. The United Kingdom (1987); R. v. The United Kingdom (1987); W. v. The United Kingdom (1987); McMichael v. The United Kingdom (1995); Johansen v. Norway (1996), Bronda v. Italy (1998), E.P. v. Italy (1999), P., C. and S. v. the United Kingdom (2002); X. v. Croatia (2008); Aune v. Norway (2010); R. and H. v. The United Kingdom (2011); Y.C. v. The United Kingdom (2012); A.K. and L. v. Croatia (2013); R.M.S v. Spain (2013); S.H. v. Italy 2015 (2015); Strand Lobben v. Norway (2017); Hasanv. Norway (2018); S.S. v. Slovenia (2018). In the Appendix, Table 1, we present basic key information about these cases.

The analytical approach to the cases was undertaken in several steps; when a judgment had a dissenting opinion, we used the reasoning of the majority. First, we mapped the factual characteristics of the 20 cases, the decision outcome, ECHR violations, family composition, age of the child, etc. Second, we analysed the Court's use of case law in relation to Article 8, ECHR, and further, if the adoption cases made reference to each other (see Tables 2 and 3 in Appendix). Third, we read the cases with the aim of identifying the main themes of the dispute in the context of Article 8 and the CRC, and analysed the Court's reasoning, argumentation and understanding in relation to two themes: the child's family life and the child's best interests. For each theme, we examined what standard the Court applies, if and how those standards change over time, and how the Court considers the specific circumstances of the case. We have emphasised the ten core cases as they include the discussions around material violations of Article 8 (in Appendix, Table 4, there are details on substantive consideration by the Court). All four researchers have

910 September 2019 the Grand Chamber judgment, Strand Lobben and others v. Norway 2019, was published, replacing the judgment from 2017. In the Grand Chamber judgment, a majority of 13 judges concluded that Norway had violated the applicants' right to respect for family life on procedural grounds - not on the merits of adoption from care. We do not include this judgment in the analysis, because it came this late and furthermore the judgment is on procedural issues. A commentary by Dr. Skivenes can be found online: https://strasbourgobservers. $\operatorname{com} / 2019 / 10 / 10 /$ child-protection-and-child-centrism-the-grand-chamber-case-of-strandlobben-and-others-v-norway-2019/. 
reviewed the judgments, and have coded and recoded themes in the material. Any discrepancies in the interpretation of the coding have been thoroughly discussed within the team until resolved. Two research assistants have reliability-tested the coding.

There are limitations to our approach, as we only base our study on the written arguments in the judgments, to the extent that they have been found admissible, and analyse the discussion of the merits of the case with regard to Article 8. Thus, we do not capture deliberations within the Court, or any non-verbal communication or other types of factors that may influence the outcome. However, for most of the cases the written material is the only source of the decision makers' reasoning, due to time having passed. In addition, the written judgments are the central component of the case law of the Court that gives an authoritative interpretation of the ECHR and is thus binding upon the member states. Therefore, judgments represent the material that forms and instructs the legal community and member states on how to interpret and apply the ECHR (see e.g. Zysset 2017: 94-96; Rainey, Wicks and Ovey, 2017: $64-83)$.

\section{$5 \quad$ Findings}

We start with a description of the characteristics of all the adoption cases decided by the Court, to provide an informative backdrop to our analysis and to bring forward knowledge about state intervention cases that we have very little information about in Europe.

\subsection{Adoption from Care Case Characteristics}

The 20 cases on adoption decided by the Court concern 25 children. In 16 cases the biological mother was an applicant; sometimes joined by the father ( $1 / 20$ cases) or the biological child who had been removed and placed for adoption (2/20 cases). In three cases, the biological father was the applicant and in one case maternal grandparents were applicants. All the applicants alleged a violation of their Article 8 right. Nine of the cases are brought against the UK, four against Norway, three against Italy, two against Croatia and one case each against Spain and Slovenia. There were 14 cases in which the children were adopted, and six cases in which the adoption process was either discontinued ( $1 / 20$ cases) or pending by the time of the ECtHR judgment ( $5 / 20$ cases). The children were between one and 15 years old at the time of adoption (nine unknown), with a median of 5.5 years and an average of 5.7 years. At the time of the decision in the Court, the children 
were between 4 and 18 years old, with a median of 9 years and an average of 9.5 years.

Most cases, as described in the judgments, provide several reasons for the necessity of intervention by the child protection authorities. Common issues are parental mental health (12/20 cases); general "parenting deficiencies" (8/20); parents' substance misuse (drug, alcohol, medicine) (7/20); domestic violence (5/20); and housing issues $(5 / 20)$. In eight cases, there are various direct or indirect problematic issues that are typically not associated with good parenting capabilities, including previous mistreatment of children, a chaotic lifestyle, and violent criminal behaviour.

The Court was composed of 7 judges in 12 cases. In another 5 cases, the Court consisted of 17 judges, and 9 judges in the remaining three cases. In 12 out of the 20 cases, the Court concluded that there had been a violation of Article 8, with four of these decisions having dissenting minority opinions. Of the eight cases, where the Court did not find a violation of Article 8 , four had a dissenting minority. Cases with violations of Article 8 concerned most often procedural issues (eight of the ten cases), whereas for the core cases there are four out of ten cases concluding on a breach. The CRC is mentioned in the Court's argumentation in $6^{10}$ of the 15 judgments (not including judgments decided before 1989), the first time in 1996 (in Johansen $v$. Norway).

We examined how the 20 adoption judgments referenced each other (cf Olsen and Küçüksu, 2017; Helland, 2019), and four judgments stand out as establishing important principles in child protection and adoptions: Johansen v. Norway (1996) is referenced in 92 per cent of the subsequent judgments, $R$. $H$. v. $U K$ (2011) is referenced in 71 per cent, Y.C. v. $U K(2012)$ is referenced in 67 per cent, and Aune v. Norway (2010) is referenced in 63 per cent of the subsequent judgments (see Table 2 in the Appendix for a detailed overview).

The ten core judgments in which the Court considers substantively the material conditions of adoption have some key characteristics (see Table 1). We find that they are all relatively new, with eight of the ten cases decided from 2010 and onward, and only two from the 199o's (1996 and 1999).Johansen v. Norway (1996) sets the scene and standards for all the coming assessments of the Court in cases of child protection and adoption from care ${ }^{11}$

10 Johansen v. Norway (1996), para. 76; Xv. Croatia (2008), para. 23; A. K. and L. v. Croatia (2013), para. 34; Strand Lobben v. Norway (2018), paras. 70, 74-75; Hasan v. Norway (2018), paras. 108, 118; S. S. v. Slovenia (2018), paras. 51, 63.

11 Although, Simmonds (2012), amongst other, raises doubts as to whether Johansen $v$. Norway (1996) and Y. C. v. UK (2012), are consistent. 


\begin{tabular}{|c|c|c|c|c|c|}
\hline Applicant, state and year & $\begin{array}{l}\text { Least } \\
\text { Intrusive } \\
\text { Measures }\end{array}$ & Re-Unification & Contact & Adoption & $\begin{array}{l}\text { Violation } \\
\text { Of Art } 8\end{array}$ \\
\hline Johansen v. Norway (1996) & & & $\mathrm{X}$ & $\mathrm{X}$ & Yes (8:1) \\
\hline E.P v. Italy (1999) & & $\mathrm{X}$ & $\mathrm{X}$ & $\mathrm{X}$ & Yes $(6: 1)$ \\
\hline Aune v. Norway (2010) & & & $\mathrm{X}$ & $\mathrm{X}$ & No $(7: 0)$ \\
\hline$R$ and $H v . U K(2011)$ & & & $\mathrm{X}$ & $\mathrm{X}$ & No $(6: 1)$ \\
\hline Y. C. v. UK (2012) & & $\mathrm{X}$ & & $\mathrm{X}$ & No $(6: 1)$ \\
\hline R. M. S. v. Spain (2013) & $\mathrm{X}$ & $\mathrm{X}$ & $\mathrm{X}$ & $\mathrm{X}$ & Yes $(7: 0)$ \\
\hline S. H. v. Italy (2015) & $\mathrm{X}$ & $\mathrm{X}$ & $\mathrm{X}$ & $\mathrm{X}$ & Yes $(7: 0)$ \\
\hline Strand Lobben v. Norway (2017) & & & & $\mathrm{X}$ & No $(4: 3)$ \\
\hline Hasan v. Norway (2018) & & & & $\mathrm{X}$ & No $(7: 0)$ \\
\hline S. S. v. Slovenia $(2018)$ & & & & $\mathrm{X}$ & No $(7: 0)$ \\
\hline
\end{tabular}

(see Table 3 in the Appendix for references between the ten judgments). In all of the ten core cases, the birth parent(s) complained about the adoption order and in six cases they also disputed contact arrangements. In four cases, there was also a complaint on the lack of reunification efforts. A breach of Article 8, ECHR was found in four cases (one of them with a dissenting opinion), and in two of the cases the Court criticised the states (R.M.S. v. Spain (2013) and S.H. v. Italy (2015)) for violating the "least intrusive means" principle, as the state could initially have done more to keep the family together. The other six cases were concluded not to violate Article 8 (of which three cases had dissenting opinions). The Court follows the logic of the national procedures starting with the first involvement of the child protection system: the child being taken into public care with visitation/access arrangements between child and parents; adoption proceedings are initiated and the child is adopted (or declared available for adoption). The cases differ in the precise point where the alleged violation of the biological parent's family life took place and the way that the violation happened. Each of these stages are together and separately considered an interference with the family life of both the child and the biological parents. In three of the cases, E.P. v. Italy (1999), R.M.S. v. Spain (2013) and S. H. v. Italy (2015), the main focus was on the first interventions by the state. The Court concluded in these cases that the states had not done enough: services and support could have been provided and contact could have been maintained. The applications in all judgments were submitted by the biological parent(s), and only in S. S. v. Slovenia (2018) adoptive parents intervened as third parties. The latter may indicate a broader perspective on family relations in the Court. 
In examining if and how the Court discusses and provides reasoning relating to "family life" for the involved children, and how the Court considers the child's best interests, in the ten core cases, a leading question is how the Court reasons around de jure and de facto family relations. In all the ten core cases, the Court first outlines the platform for the analysis - the basic criteria and case law for Article 8. The Johansen v. Norway (1996) judgment states the basic standard for an intervention, which is quoted or referred to in seven out of ten judgments: ${ }^{12}$

'Such measures should only be applied in exceptional circumstances and could only be justified if they were motivated by an overriding requirement pertaining to the child's best interests' (para. 78 ).

Subsequent cases elaborate on the types of circumstances that are "exceptional" and the requirements that are "overriding", so that the initial family unit may be permanently dissolved, leading to the termination of rights flowing from that unit, as courses of action that are in the child's best interests. The findings from the Court's reasoning in each of the ten core cases presented in the following, in chronological order, see also Table 2.

Johansen $v$. Norway (1996) concerns a girl who shortly after birth was taken into care by the child protection authorities due to the mother's poor physical and mental health and an incapability to care for the baby. The girl was later adopted. The Court finds the care order necessary, but concludes (8:1) that contact arrangements and adoption constituted a violation of Article 8. In this case, the Court considers Article 8 also to include the child. Here, the child's best interests considerations concerned the child's developmental needs and the Court also comments on the advantages of an adoption:

it was crucial that she live under secure and emotionally stable conditions. The Court sees no reason to doubt that the care in the foster home had better prospects of success if the placement was made with a view to adoption (para. 80).

12 The exceptions are E. P. v. Italy (1999) which instead make reference to the standard of 'necessary in a democratic society' (para. 61); R. M. S. v. Spain (2013) that refer to the standard to, 'ensure compliance with the positive obligations imposed on it under Article 8 of the Convention' (para. 5); and, S. S. v. Slovenia (2018) that refers to the standard of 'exceptional circumstances' (para. 96), but do not connect this to the best interests principle or make reference to the Johansen $v$. Norway (1996) case. 


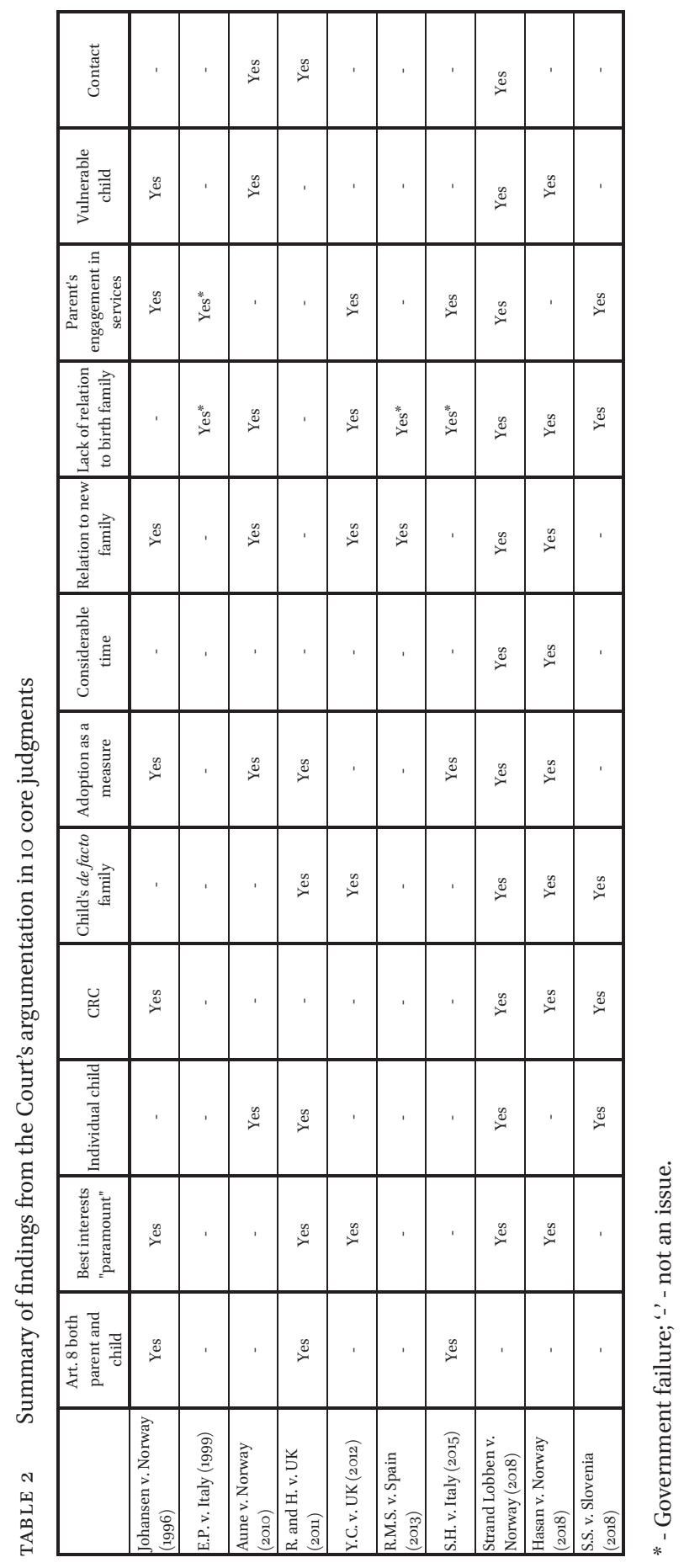


The Court also considers the fact that the mother was not being receptive to treatment, and feared that she might take her daughter away. In the Court statements on family life, it is the mother's family life that is explicitly mentioned but the simultaneous violation of the child's right to respect for family life (with her mother) is not a focus in the Court's formulation of family life.

The E.P. v. Italy (1999) case concerns a girl who at about age five was removed from her mother by the child protection authorities due to the mother's mental health problems and her seemingly obsessive focus on the child's health. The mother and the child were not allowed any contact after the removal, and the girl was freed for adoption. The Court only briefly considers the best interests of the child, as it concludes (6:1) a breach of Article 8 , because mother and child had not had a chance to re-establish their bonds and this was not a fair balance between the best interests of the child and the mother's Article 8 rights.

Aune v. Norway (2010) is a case about a boy who was removed from his parents at age six months, due to abuse and his parents' serious drug problems. The boy was later adopted. When the Court assesses if an adoption was anchored in his best interests, it considers three factors: first, that the mother had created great disturbances around the boy's placement. Second, that the boy is particularly vulnerable and in need of security. Third, that contact between the birth family and the boy would continue after an adoption. In this case, the child's view is mentioned, as the Court saw, 'no reason to doubt that the impugned measures corresponded to A's wishes' (para. 72). The Court unanimously concluded that there had not been a breach of Article 8.

$R$. and H. v. UK (2011) related to a girl who was taken into care by the child protection authorities in Northern Ireland, due to the mother's alcohol misuse and mental health problems. The child was adopted at a later stage, which started with an order that freed the child for adoption. In the best interests analysis, the Court considers the timescale for the parents to deal with their alcohol problem and, being mindful of the possibility of a relapse, notices that '(a)ny such relapse would be "catastrophic" for N (child)' (para. 85). It also addresses if post-adoption contact should be a requirement, and concludes that both these factors had to give way to the child's interest in having the opportunity to be adopted. In the Court's discussion of family life, the Court is explicit that it is the 'protection of the rights of parents and children to respect for their family life' (para. 81). In this case, the Court points to the individuality of children in the same family, stating that

'the needs and interests of children, even children in the same family, may vary greatly according to their age. The domestic authorities were 
entitled to make different decisions as to the care of all the children concerned in this case, and to find that that N's age meant that adoption was in her best interests' (para. 86).

Also interesting is that in this case, the Court concurs with the state's argument that it is inconsiderate of the parents not to consent to adoption when that is clearly in the best interests of the child. Finally, the Court explicitly mentions the child's de facto family situation:

'when a considerable period of time has passed since a child was originally taken into public care, the interest of a child not to have his or her de facto family situation changed again may override the interests of the parents to have their family reunited ...' (para. 88).

The Court concludes (6:1) that there was no breach of Article 8 .

Y. C. v. $U K(2012)$ is a case about a boy who was seven years old when he was first removed from his parents due to the parents' misuse of alcohol, domestic violence and parental incapacities. The Court, for the first time, stated explicitly the factors that must be assessed when considering the child's best interests:

The identification of the child's best interests and the assessment of the overall proportionality of any given measure will require courts to weigh a number of factors in the balance. The Court has not previously set out an exhaustive list of such factors, which may vary depending on the circumstances of the case in question. However, it observes that the considerations listed in section 1 of the 2002 Act [Adoption and Children Act 2002] ... broadly reflect the various elements inherent in assessing the necessity under Article 8 of a measure placing a child for adoption. In particular, it considers that in seeking to identify the best interests of a child and in assessing the necessity of any proposed measure in the context of placement proceedings, the domestic court must demonstrate that it has had regard to, inter alia, the age, maturity and ascertained wishes of the child, the likely effect on the child of ceasing to be a member of his original family and the relationship the child has with relatives (para. 135) (authors' insertion in brackets).

The Court considers the timescale and the request for further assessment of parental capacities, and notes that this '... would entail a degree of disruption to K.'s foster placement and a risk of emotional harm...' (para. 145). Another factor that is mentioned is the parents' lack of engagement with support and services. The Court concludes (6:1) that there was not a breach of Article 8 in this case. 
R. M. S. v. Spain (2013) concerns a girl who was under the age of four when the child protection authority removed her from her mother. The Court's assessment and considerations focus on the initial proceedings and the lack of reasoning and examination by the public authorities. The Court's discussion of the interests of the child stresses the lack of evidence and examination of the child's situation:

'the decision in question should have been followed swiftly by appropriate measures to examine in depth the child's situation and her relationship with her parents' (para. 83).

The Court emphasises the age of the child as a factor that makes the intrusive intervention especially serious, and the Court is not persuaded by the Spanish authorities' descriptions of the relationship between mother and child and the behaviour of the mother and the conclusions drawn by the decision makers:

The Court notes that no consideration was given at any stage of the administrative procedure to the fact that the child had been very young when she was separated from her mother, to the existing emotional bond between mother and child or to the length of time that had elapsed since their separation and the attendant consequences for both of them (para. 83).

The Court found unanimously a violation of Article 8 .

S. H. v. Italy (2015) is a case about a girl who was four at the time of the removal from her mother by the Italian authority. There were concerns about the mother's mental health, and several accidental ingestions of medication by the child that resulted in hospitalisations. The Court found a violation of Article 8 in this case (6:1), and Article 8 included also the child. In the discussion of the girl's best interests, the Court criticises the lack of support and problem-solving by the child protection system. This resulted in 'insufficient effort to safeguard the bond between the mother and the children' (para. 52). The Court is clear that programmes of social assistance were available which 'would have preserved the family bond while also protecting the children's best interests' (para. 52). The Court discusses the family life of the child solely in relation to the birth family, and there is no mentioning of the child's de facto situation or discussion of other best interests considerations such as the child's needs or attachment to her mother or other important persons.

The Strand Lobben v. Norway (2017) case concerns a boy who was a newborn baby when he was first removed from his mother by the child protection 
authorities due to concerns about the mother's caring abilities. The Court has an extensive discussion on the child's best interests and family life. First, with reference to CRC General Comment No. 7 (2005), the Court finds that it is particularly important to secure the rights of a child of a young age. Second, the boy's particular care needs are vital:

'...clearly guided by the interests of $X$ (child), notably his particular need for security in his foster-home environment, given his psychological vulnerability' (para. 129).

Third, the Court acknowledges that while the removal of the child was within the state's margin of appreciation, the best interests assessment 'must in the present case be carried out taking account of the alternatives that lay in continued foster care' (para. 121). This is the first of the current cases in which the Court explicitly uses this platform as a departure point. Fourth, the Court points to the relations between child and parent when in contact:

'Taking also into account the City Court's conclusion that there had been no positive development in the first applicant's competence in contact situations throughout the three years in which she had had rights of access' (para. 129).

Fifth, in connection with the protection of the child's family life, the Court emphasised several times that the de facto family situation is important and must be protected. The Court concluded (4:3) that there was no breach of Article 8.

Hasan v. Norway (2018) concerns two sisters who were removed from their family by the child protection system at age one (during the first removal) and as a baby, respectively. The reason for the intervention was severe family violence, with the mother fleeing to a rescue centre, threats by the father and the abduction of the children and threats of violence by the father's family. In this case, the Court has an extensive discussion of the case law criteria for violation of Article 8 in relation to the child's best interests:

'Where children are involved, their best interests must be taken into account. The Court reiterates that there is a broad consensus, including in international law, in support of the idea that in all decisions concerning children, their best interests are of paramount importance ...' (para. 149). 
Furthermore, the Court analyses balancing between the birth family and the de facto family situation of the child:

'The best interests of the child dictate ... that the child's ties with its family must be maintained, ... When a "considerable period of time" has passed since the child was first placed in care, the child's interest in not undergoing further de facto changes to its family situation may prevail over the parents' interest in seeing the family reunited...' (para. 150).

The Court emphasises in its consideration of the best interests of the children, first, that the children do not have an attachment to their mother, and that their attachment to the foster parents was so strong that it would be harmful to remove them. Second, the Court draws attention to the children's need for protection from being abducted, that they were vulnerable, and that there had been considerations in relation to each individual child needs. Third, the Court also makes a statement in relation to adoption:

'Replacing the children's legal ties to the applicant with legal ties to the adoptive parents thus served to consolidate their de facto family ties. The Court has previously held that where social ties between a parent and his or her children have been very limited, "( $t$ )his must have implications for the degree of protection that ought to be afforded to (the parent's) right to respect for family life under paragraph 1 of Article 8 when assessing the necessity of the interference under paragraph 2"' (para. 161).

The Court concludes unanimously that there was no breach of Article 8.

S. S. v. Slovenia (2018) concerns a girl who was removed by the child protection authorities when she was one month old. The reason for concern was the mother's mental health problems and abandonment of the girl. The Court lays out the various criteria, and includes a reference to the child's interest in maintaining the present family situation and relates this directly to adoption:

'Equally, when a considerable period of time has passed since a child was originally taken into public care, the interest of a child not to have his or her de facto family situation changed again may override the interests of the parents to have their family reunited ... Thus, in the field of adoption, the Court had already accepted that it may be in the child's interest to promote the process of establishing bonds with his or her foster parents ...' (para 86). 
The Court concludes unanimously that there was no breach of Article 8 .

In the best interests assessment, the Court points out, first, that the child and the mother lacked an emotional connection between them, and, second, that contact sessions had a negative impact on the child. Third, an interesting statement from the Court is that even when there are some prospects for reunification, the interests of the child may override this possibility, and the Court points out the balancing between keeping legal ties versus the child's need to be fully integrated into her de facto family:

Even in a situation where reunification might be possible at some point in the future, the interest of a child not to have his or her de facto family situation changed after a considerable period of time may override the interests of the parents in having their family reunited ... By the same token, in view of there being little or no prospect of the biological family's reunification, the Court considers that E.'s [child] interest in fully integrating into her de facto family weighed particularly heavily in the balance when assessed against the applicant's wish to retain legal ties with her (para. 101).

In Table 2 we have summarised the findings from the ten core cases, and for transparency reasons we have done the same for all adoption cases $(n=20)$ in Table 4 in Appendix.

Discussion

As an initial and general observation, our findings suggest that the Court regards children as objects rather than subjects and that consideration of "family life" is limited to the rights of parents. However, some important developments are emerging, seemingly taking the Court in a child centric direction. Traditionally, the cases arise from disputes that are centrally about children but the disputes themselves are played out between biological parents and the state. In child removal and adoption cases, the best interests of the child principle serves to limit the right to respect for family life contained in Article 8(1) but the question remains as to whether such interference and thus indirectly the standard of the best interests of the child as a limitation on other (predominantly biological) family members' right to respect for family life - is justified (i.e. "necessary in a democratic society") under Article 8(2). This situation also raises the question of whether the standard of the best interests of the child also serves to create and/or protect new familial 
(and, in the context of this article, non-biological) relationships, i.e. that the child's de facto family situation is secured by de jure bonds. Our analysis of the Court's judgments identifies some further, more nuanced, developments that have taken place.

\subsection{Child Centric Developments in Article 8Jurisprudence}

First, there appears to be a tendency to give increasing focus to the child's perspective in these cases. This is evidenced by the following three factors: the Court opens up for describing the breach of family bonds concerning both the parents and the child when referring to Article 8 ECHR (Johansen v. Norway (1996); R. and H. v. UK (2011); S. H. v. Italy (2015)). This may be an indication that the Court recognises that children and their rights are protected by the ECHR. Furthermore, the standard of the child's best interests being paramount is mentioned in five of the judgments, thus explicitly drawing attention to the higher standard applicable in cases of adoption (Zermatten, 2010). Finally, the Court underscores the importance of assessments of the individual child's needs and interests in three cases (Aune $v$. Norway (2010), Strand Lobben v. Norway (2017), S. S. v. Slovenia (2018)), as opposed to an assessment of the general child. ${ }^{13}$ This includes the Court being explicit that children in the same circumstances, e.g. being siblings, have different needs and interests. In conjunction with these developments, there is an increase in references to the CRC in the core judgments (four cases), and this is particularly evident in the Court's three latest judgments.

Second, the Court has gone beyond recognising de jure family as the "only" family unit that is protected by Article 8, and the child's de facto family situation is introduced as a standard and explicit consideration: First in $R$. and H. v. UK (2011), thereafter in Y. C. v. UK (2012), and is also referred to several times in all the three last cases from 2017-18. Even though the Court has recognised protection afforded to the de facto family in its previous case law as a tool for accepting different types of family units (O'Mahony, 2012), substantive focus on the de facto relations of the child has been narrow (Kilkelly, 2017: 159). Unlike other types of cases, adoption disputes include at least two family units that potentially deserve protection under Article 8. Focus on the de facto family is an important change in the Court's focus, signifying that the child's (and foster parents') family life is of significance and important to protect. The Court explicitly mentions the combination of de jure

13 In Grand Chamber judgment Strand Lobben and others v. Norway, the majority of 13 underscored the importance of including information about the specific child in the case (para. 224). 
and de facto family in the latest judgment (S. S. v. Slovenia (2018)), stating that for a child being integrated into the de facto family weighed particularly heavily when balanced with the biological parent's wish to retain legal ties. Furthermore, the Court acknowledges the value of securing a de facto placement with de jure bonds, and that the alternative in these cases is not birth family versus adoptive parents, but foster home versus adoptive family (Strand Lobben v. Norway (2017)). The latter development also impacts on the earlier understanding of the principle that all state interventions into the family should be temporary. The Court now recognises that placements of children may become permanent, where this is in the child's best interests. Furthermore, and as stated in S. S. v. Slovenia (2018), even when reunification may be a possibility in the future, where the child's interests are best served by a permanent placement with her de facto family, considerations of the benefits of more immediate permanency can override this consideration, which may be a longer-term outcome; a conclusion that features in the remaining developments that we identify.

Third, the Court acknowledges explicitly in six of the judgments (Johansenv. Norway (1996), Aune v. Norway (2010), R. and H. v. UK (2011), S. H. v. Italy (2015), Strand Lobben v. Norway (2017), and Hasan v. Norway (2018)) that adoption is a measure that in general has advantages, e.g. '...placement was more likely to be successful if the child was adopted by the foster parents' (Johansen 1996, para. 77). The Court also includes the advantages of adoption for the foster parents, as in Hasan v. Norway (2018):

As regards the authorisation of adoption, the Court further notes that the City Court based its decision on how adoption offered many advantages compared with placement in a permanent foster home, particularly in the form of a higher degree of security, both for the foster parents and for the children (para. 157).

Fourth, is the time factor, closely connected to the child's need for stability (Kilkelly, 2017: 353). Time is a critical element in the Court's assessment of attachment of the child and the child's interest in preserving the de facto family situation, as is emphasised in R. and H. v. UK (2011). "Considerable time" is the term used, and in Strand Lobben v. Norway (2017), three years and six months is regarded as considerable time. Later, in Hasan v. Norway (2018), considerable time is three years and three months.

Clearly, the material from which to draw conclusions is still too sparse, but the tendencies we have detected in which the Court identifies factors that are directly related to the child's de facto family situation are noticeable. 


\subsection{Article 8, Jurisprudential Developments Regarding the Child's Best Interests}

On the substantive or material understanding of the child's best interests standard, a standard that all cases refer to, we identify five factors that the Court pays attention to in the adoption cases.

First, the child's relations and attachment to foster/adoptive family is a consideration, and the Court mentions this in six cases (Johansen v. Norway (1996); Aune v. Norway (2010); Y. C. v. UK (2012); R. M. S. v. Spain (2013); Strand Lobben v. Norway (2017); Hasan v. Norway (2018)). In the three last cases, the Court mentions the positive and strong relationship between the child and foster parents. The Court has also recognised that the child's integration into the new family and relationship with her adoptive parents can serve to ameliorate the harm previously suffered by the child, as well as the potential harm that might accrue to the child should the new relationship be broken (cf. Kilkelly, 2017 on other types of adoption judgments).

Second, the child's lack of relation to birth parents is mentioned as a factor in support of adoption; the presence or absence of such a relationship has been measured in terms of the number and success of contact sessions and meetings. It is clear that in eight of the cases, the bonds between birth parents and child are weak or non-existing. For three of these cases (E. P. v. Italy (1999), R. M. S. v. Spain (2013), S. H. v. Italy (2015)), the ECtHR criticised the respective governments for being responsible for the breach of the relationship between child and parent, whereas in the remaining cases, the lack of relationship between birth parent and child is mentioned as a ground for adoption.

Third, and related to the above point, the Court has taken into account the parents' willingness to engage in services, to use support and take on advice to improve their situation in six cases. In one case, the Court discusses the failure of the state to provide appropriate services for the parent. A further factor considered are the will and capabilities of parents to learn and improve in relation to establishing or maintaining bonds with their child.

Fourth, the Court appears to recognise the specific child's vulnerability and needs and interests as dependent on age, previous experiences and personality. This is evident in four cases, and here in particular, the child's need for security and permanency seem to be important considerations, which should be seen in relation to the previous turbulence in the child's life due to neglect and/or abuse, but also the mere fact that the child has already experienced a child protection removal, and thus a break in relations and change in living situation.

Fifth, contact after adoption is a consideration that is mentioned by the Court as a factor in three cases, and post-adoption contact counts as positive 
for the child both in terms of the contact with birth family for the child's identity and self-understanding, but also as an indication of the foster/adoptive parents' abilities to care for the child in his/her best interests.

However, although the child's best interests may be at the core of the decision-making, one feature that is lacking in much of the Court's jurisprudence is the incorporation of the child's views of what is in her best interests, or indeed the general absence of independent representation for the child in such matters. As such, only two of the ten core adoption cases make explicit reference to the child's views and opinions (Y. C. v. UK (2012) and Aune v. Norway (2010)). This potential oversight reflects in many ways the broader questions about the application of children's rights and their exercise by children themselves. These questions are important because in many countries' child protection legislation, the opinion of the child is an essential component for defining the child's best interests (Skivenes and Sørsdal, 2018), a point that underpins the views of the CRC Committee as developed in its General Comment No. 14 on the interpretation of the child's best interests principle.

\section{7 \\ Concluding Remarks}

One of the aims of this paper was to discover how the Court understands "family unit" and the ensuing "family life", and what set of familial circumstances can allow for the justifiable interference with the right to respect for family life under Article 8, ECHR. The question of the family unit's ability - or inability to provide an adequate level of family life is typically measured in terms of the child's best interests that may justify such intervention. Therefore, it is important to understand what the Court means by a "family unit" and the "child's best interests", because this meaning influences the interpretation of family life and the child's best interests.

Our analysis is particularly novel as it adds to the current and extensive body of case law and corresponding scholarly analysis on the topic of the best interests standard and the right to respect for family life by demonstrating how the child's best interests standard is used by the Court as a legal mechanism to assess the actions of states' decisions to break and recreate family units. In short, our research reveals what kind of "family unit" the ECtHR considers is in the child's best interests to dissolve. The data in Table 1 of the Appendix provides a "factual snapshot" of the characteristics of the children and their family units that were the subject of adoption from care orders, characteristics that underpinned the Court's assessment of whether states' decision making 
respected the right to respect for family life. Importantly, our findings also add to current understanding of such determinations, as we identify whether and to what extent the child's views (explicitly or implicitly) form part of the deliberations of whether it is in the child's best interests to break and recreate family units.

The Court's understands "family unit" in the context of adoptions from care, to mean biological relationships between children and parents but, more recently, also between children and foster parents, and to a more limited extent in terms of recognition, between siblings themselves. To this extent, our findings with regard to the Court's understanding of family composition are in line with the theoretical literature, wherein the concept of family reflects the bonds created by personal, caring relationships and activities.

The status and respect of the child's de facto family life is changing. This resonates with a view that children do not only have formal rights but that they are recognised as individuals within the family unit that states and courts must address directly. Born into a family, a child is born into a private, non-public sphere. As the Court's judgments on adoptions from care so blatantly show, this is a sphere that may also be oppressive, dangerous and requiring intrusive interventions from the state to protect life and wellbeing of individuals. The interesting and paradoxical theme in adoption from care cases is that the birth family, both in case law and principles, is regarded as the superior family. Even children who will not be reunified with their birth parents, and will grow up in public care, do not have the recognition of their de facto family by providing them with legal protection of their family life. The changes we find in the Court's view on and understanding of family for children entails a recognition and stronger protection of children's non-biological and de facto family life. From a state perspective this make sense, as the state cannot and should not be a primary parent - that is, having the responsibility and joy of the family institution. The development we have shown has similarities with the women's rights movement and the realisation that families are not only a heaven of love and care, operating under other conditions than the State, but also a coercive and neglectful unit, dangerous for the family members.

The analysis indicates some further developments concerning the inter-relationship between the ECHR and the CRC with regard to the best interests standard. Although the number of instances in which the Court identifies the CRC as relevant law is increasing, the Court's reliance on "best interests" as an analytical tool stems from the states' own domestic legislation, and not as it appears in the CRC (cf. Tobin, 2013). This raises the question of the relevance of the CRC generally, and its consideration of the best interests standard in 
relation to the preservation, or otherwise, dissolution of the family unit. Whilst the $\mathrm{CRC}$, from the perspective of international legal rules, cannot directly impact on the interpretation of Article 8 of the ECHR, a failure to outline the CRC s approach to the continued care of children by their families, where it is in the child's best interests, cannot be overlooked. States themselves ought to be mindful of their binding obligations under the CRC to act in the best interests of the child, and so their domestic legislation ought to reflect that obligation. It is noteworthy that the CRC Committee has expressed concern in relation to the manner and/or extent to which the six member states our study comprises ensure that "the best interests of the child" appropriately informs the situation of children in alternative care. As states move to address such concerns, it may be that the CRC indirectly influences the best interests standard that falls to be considered by the ECtHR in later cases. Our study provides some insight into the types of factual situations, and thus some concrete examples of family units and family life that are not in the child's best interests, a level of detail that has been absent from the CRC's analysis, prior to the adoption of its complaints mechanism and which may also provide a point of future comparison as the jurisprudence of the complaints mechanism continues to expand and develop.

The private and public nature of the family, regarded as the fundamental unit of society with both individual/private and public ends, requires a fine balance to be struck between the avoidance of state intervention and the obligation of the state to protect individual members; this need for careful consideration is perhaps nowhere as clearly demonstrated in decision-making as where it may result in the involuntary and permanent dissolution of the core unit of societal relationships, to facilitate the recreation of a new family unit that better serves the interests of the child.

\section{Acknowledgement}

We are grateful for helpful comments from reviewer and journal editor. We have received insightful feedback on earlier versions of the paper at the seminar series, "Law, Democracy and Welfare state" in Bergen as well as at seminar series at OsloMet.

This project has received funding from the European Research Council (ERC) under the European Union's Horizon 2020 research and innovation program (grant agreement no. 724460) and from the Research Council of Norway under the Independent Projects - Humanities and Social Science program (grant no. 262773). 


\section{References}

Archard, D., The family. A Liberal Defence (London: Palgrave Macmillan, 2010).

Asche, J., Die Margin of Appreciation. Beiträge Zum Ausländischen Öffentlichen Recht Und Völkerrecht. [The Margin of Appreciation. Contribution to Foreign Public Law and International Law] (Berlin: Springer, 2017).

Banda, F. and Eekelaar, J., "International Conceptions of the Family", International and Comparative Law Quarterly 2017, (66 (4)), 833-862.

Berrick, J. D., N. Gilbert and M. Skivenes (eds.), International Handbook of Child Protection Systems (NY: Oxford University Press, in press).

Burns, K., Pösö, T. and Skivenes, M. (eds.), Child Welfare Removals by the State: A CrossCountry Analysis of Decision-Making Systems (New York, NY: Oxford University Press, 2017).

Cutas, D., "The composition of the family" in A. Gheaus, G. Calder and J. De Wispelaere (eds.), The Routledge Handbook of the Philosophy of Childhood and Children (London: Routledge, 2018).

Directorate of the Jurisconsult, "Guide on Article 8 of the Convention - Right to Respect for Private and Family Life" (European Court of Human Rights, 31 August 2019): https:// www.echr.coe.int/Documents/Guide_Art_8_ENG.pdf, accessed 24 October 2019.

Dzehtsiarou, Kanstantsin, "European Consensus and the Evolutive Interpretation of the European Convention on Human Rights", German Law Journal 2011 (12), 1730-1745.

ECtHR, Johansen v. Norway (II) (Admissibility decision), Application No. 12750/o2, 10 October 2002: http://hudoc.echr.coe.int/eng?i=001-22752, accessed 26 June 2019.

ECtHR, "Guide on Article 8 of the Convention - Right to Respect for Private and Family Life", 2019: https://www.echr.coe.int/Documents/Guide_Art_8_ENG.pdf, accessed 27 June 2019.

Eekelaar, J., "The Role of the Best Interests Principle in Decisions Affecting Children and Decisions about Children", The International Journal of Children's Rights 2015 (23 (1)), 3-26.

Fenton-Glynn, Claire, “The Child's Voice in Adoption Proceedings: A European Perspective", The International Journal of Children's Rights, 2013 (21(4)), 59o-615.

Gilbert, N., Parton N. and Skivenes M., "Conclusion" in N. Gilbert, N. Parton and M. Skivenes (eds.), Child Protection Systems: International Trends and Emerging Orientations, (pp. 243-259) (New York, NY: Oxford University Press, 2011).

Hanson, K. and Lundy, L., "Does Exactly what it says on the Tin? A Critical Analysis and Alternative Conceptualisation of the so-called 'General Principles' of the Convention on the Rights of the Child", International Journal of Children's Rights $2017(25(2)), 285-306$. 
Helland, Trond., "Care order cases in the European Court of Human Rights. Parents' vs. children's rights” (University of Bergen: Department of Political Science, 2019).

Hodson, Loveday., "Ties That Bind: Towards a Child-Centred Approach to Lesbian, Gay, Bi-Sexual and Transgender Families under the ECHR", International Journal of Children's Rights $2012(20(4)), 501-522$.

Kilkelly, U., "Protecting Children's Rights under the ECHR: The Role of Positive Obligations", Northern Ireland Legal Quarterly 2010 (61(3)), 245-61.

Kilkelly, U., "The Child and the European Convention on Human Rights" 2nd edn. (London: Routledge, 2017).

Kilkelly, U and Bracken, L., "Commentary on Gas and Dubois v. France", in H. Stalford, K. Hollingsworth and S. Gilmore (eds.), Re-Writing Children's Rights Judgments: From Academic Vision to New Practice" (New York: Oxford University Press 2017).

Lagoutte, S., "The Right to Respect for Family Life of Children of imprisoned Parents", International Journal of Children's Rights 2016 (24(1)), 204-230.

Olsen, H. P. and Kücüksu, A., "Finding hidden patterns in ECtHR's case law: On how citation network analysis can improve our knowledge of ECtHR's Article 14 practice", International Journal of Discrimination and Law 2017 (17(1)), 4-22.

O'Mahony, C., "Irreconcilable differences - article 8 ECHR and Irish law on non-traditional families", International Journal of Law, Policy and Family 2012 (26(1)), 31-61.

O'Mahony, C., "Child Protection and the ECHR:Making Sense of Positive and Procedural Obligations", International Journal of Childrens Rights 2019 (27(in press)).

Rainey, B., Wicks, E. and Ovey, C., "The European Convention on Human Rights" (NY: Oxford University Press, 2017, $7^{\text {th }}$ edn.).

Rawls, J., "Justice as Fairness: A Restatement", (Cambridge: Harvard University Press, 2001).

Reece, H., "The Paramountcy Principle”, Current Legal Problems 1996 (49(1)), 267-304.

Satz, D., "Feminist Perspectives on Reproduction and the Family", The Stanford Encyclopedia of Philosophy (Summer 2017 edition), Edward N. Zalta (ed.): https:// plato.stanford.edu/archives/sum2017/entries/feminism-family/, accessed 26 June 2019.

Sharma, R., "The family and family structure classification redefined for the current times.", Journal of Family Medicine and Primary Care 2013 (o2(4)), 306-310.

Simmonds, C., "Paramountcy and the ECHR: A Conflict Resolved?", The Cambridge Law Journal 2012 (71(3)), 498-501.

Skivenes, M., "Child protection and child-centrism - the Grand Chamber case of Strand Lobben and others v. Norway 2019", Strasbourg Observer 2019: https:// strasbourgobservers.com/2019/10/10/child-protection-and-child-centrism-the-grandchamber-case-of-strand-lobben-and-others-v-norway-2019/, accessed 22 October 2019.

Skivenes, M. and Sørsdal, L., "The child's Best Interest Principle across Child Protection Jurisdictions", in E. Backe-Hansen and A. Falch-Eriksen (eds.), Child Protection and 
Human Rights - Implementing the CRC in Policy and Professional Practice (59-88) (London: Springer, 2018).

Sloan, B., "Conflicting Rights: English Adoption Law and the Implementation of the UN Convention of the Rights of the Child", Child and Family Law Quarterly 2013 (25(1)), 40-6o.

Spano, Daniela, "The Composition of the Family" in Gheaus, A., Calder, G. and De Wispelaere, J. (eds.), The Routledge Handbook of the Philosophy of Childhood and Children, 2018 (Routledge).

Tobin, J., “Justifying Children' Rights", The International Journal of Children's Rights $2013(21(3)), 395^{-441 .}$

Van Bueren, G., "Child Rights in Europe: Convergence and divergence in judicial protection" (Council of Europe, 2007).

Wheatle, S., "Principled Reasoning in Human Rights Adjudication", Hart Studies in Comparative Public Law (Portland, OR: Hart Publishing, 2017).

Zermatten, J., “The Best Interests of the Child Principle: Literal Analysis and Function”, The International Journal of Children's Rights 2010 (18(4)), 483-499.

Zysset, A., "The ECHR and Human Rights Theory" (London: Routledge Research in Human Rights Law, 2018).

\section{The Committee on the Rights of the Child, comments, observations and reports}

Committee on the Rights of the Child, General Comment No. 12, The right of the child to be heard (2009) (CRC/C/GC/12) (20 July 2009).

Committee on the Rights of the Child, General Comment No. 14 (2013) on the right of the child to have his or her best interests taken as a primary consideration (art. 3, para. 1) (CRC/C/GC/14), 29 May 2013.

Committee on the Rights of the Child, General Comment No. 7 (2005), Implementing child rights in early childhood (CRC/C/GC/7/Rev.1), 2o September 2006.

Committee on the Rights of the Child, General Comment No. 20 (2016) on the implementation of the rights of the child during adolescence (CRC/C/GC/2O), 6 December 2016.

Committee on the Rights of the Child and the Committee on the Protection of the Rights of All Committee on the Rights of the Child Migrant Workers and Members of Their Families, Joint General Comment No. 3 (2017) of the Committee on the Protection of the Rights of All Migrant Workers and Members of Their Families and No. 22 (2017) of the Committee on the Rights of the Child on the general principles regarding the human rights of children in the context of international migration, CRC/C/GC/22, (16 November 2017). 
Committee on the Rights of the Child, 1996a, Concluding Observations on the Rights of the Child: Croatia, CRC/C/15/Add.52, 13 February 1996.

Committee on the Rights of the Child, 1996b, Consideration of Reports Submitted by States Parties under Article 44 of the Convention, Concluding Observations of the Committee on the Rights of the Child: Slovenia, CRC/C/15/Add.65, 30 October 1996.

Committee on the Rights of the Child, 200o, Consideration of Reports Submitted by States Parties under Article 44 of the Convention, Concluding Observations: Norway, CRC/C/15/Add.126, 28 June 2000.

Committee on the Rights of the Child, 2002a, Consideration of Reports Submitted by States Parties under Article 44 of the Convention, Concluding Observations of the Committee on the Rights of the Child: Spain, CRC/C/15/Add.185, 13 June 2002.

Committee on the Rights of the Child. 2002b, Consideration of Reports Submitted by States Parties under Article 44 of the Convention, Concluding Observations of the Committee on the Rights of the Child: United Kingdom of Great Britain and Northern Ireland, CRC/C/15/ Add.188, 9 October 2002.

Committee on the Rights of the Child, 2003, Consideration of Reports Submitted by States Parties under Article 44 of the Convention, Concluding Observations: Italy, CRC/C/15/Add.198, 18 March 2003.

Committee on the Rights of the Child, 2004a, Consideration of Reports Submitted by States Parties under Article 44 of the Convention, Concluding Observations of the Committee on the Rights of the Child: Slovenia, CRC/C/15/Add.23o, 26 February 2004.

Committee on the Rights of the Child, 2004b, Consideration of Reports Submitted by States Parties under Article 44 of the Convention, Concluding Observations of the Committee on the Rights of the Child: Croatia, CRC/C/15/Add.243, 3 November 2004. Committee on the Rights of the Child, 2005, Consideration of Reports Submitted by States Parties under article 44 of the Convention, Concluding Observations: Norway C/C/15/Add.263, 21 September 2005.

Committee on the Rights of the Child, 2010a, Consideration of Reports Submitted by States Parties under article 44 of the Convention, Concluding Observations: Norway $\mathrm{CRC} / \mathrm{C} / \mathrm{NOR} / \mathrm{CO} / 4$ (3 March 2010).

Committee on the Right of the Child, 201ob, Consideration of Reports Submitted by States Parties under article 44 of the Convention Concluding Observations: Spain, $\mathrm{CRC} / \mathrm{C} / \mathrm{ESP} / \mathrm{CO} / 3_{-4}, 3$ November 2010.

Committee on the Rights of the Child, 2011, Consideration of Reports Submitted by States parties under Article 44 of the Convention, Concluding Observations: Italy, CRC/C/ITA/CO/3-4, 31 October 2011.

Committee on the Rights of the Child, 2013, Consideration of Reports Submitted by States Parties under Article 44 of the Convention, Concluding Observations of the Committee on the Rights of the Child: Slovenia, CRC/C/SVN/CO/3-4, 8 July 2013. 
Committee on the Rights of the Child, 2014, Concluding Observations on the Combined Third and Fourth Periodic Reports of Croatia, CRC/C/HRV/CO/3-4, 13 October 2014. Committee on the Rights of the Child, 2016, Concluding Observations on the Fifth Periodic Report of the United Kingdom of Great Britain and Northern Ireland CRC/C/GBR/CO, 12 July 2016.

Committee on the Rights of the Child, 2018a, Concluding Observations on the Combined Fifth and Sixth Periodic Reports of Spain, CRC/C/ESP/CO/5-6, 5 March 2018.

Committee on the Rights of the Child, 2018b, Committee on the Rights of the Child, Concluding Observations on the Combined Fifth and Sixth Periodic Reports of Norway, CRC/C/NOR/CO/5-6, 1 June 2018. 